\title{
EMIGRATION, REMITTANCES AND ECONOMIC GROWTH IN THE BALTIC STATES: A REGIONAL PERSPECTIVE
}

\author{
Magdaléna Př́ivarová \\ University of Economics in Bratislava, Bratislava, Slovak Republic
}

The Baltic States have been facing higher emigration flows since joining the EU in 2004. While integrating to the EU, this region has faced many economic and political issues, which revealed the weaknesses of their economic policies, financial systems and social security systems. Even though after the EU accession in 2004 the Baltic economies have demonstrated rapid economic growth, still their financial performance under the economic crisis has evidently shown their weaknesses. The Baltic States is a crucial example of the regions where the current emigration has drawn the attention of the policy-makers seeking to reduce the possible negative effects from the emigration of young and well-skilled workers. Here, we have employed fixed effects and OLS estimation methods to conduct our research analysis. Our regression analysis has demonstrated that remittances positively and significantly contribute to the economic growth of the Baltic. However, we also need to emphasize the importance of further analysis of the geography of remittances to the region, especially under the conditions of Brexit, given the fact that for many years a large share of remittances the Baltics were receiving from the United Kingdom. The effects of Brexit on the remittances flows from the United Kingdom to the Baltics will definitely take place in the future, thus, shifts in emigration flows and remittances should be in the focus of future research.

Keywords: emigration; remittances; economic growth; Baltic states; Brexit

\section{Introduction}

Emigration from the Baltics has increased considerably over the past decades, a phenomenon that has enhanced radically since the Baltic countries joined the EU back in 2004. Emigration of population is reflected in very high negative net migration rates and thus results in substantial depopulation. Very fast economic growth following the EU accession resulted in dropping emigration rates to a certain extent though. However, since 2008 the emigration rates have been increasing again. Lithuania, in particular, has faced the highest

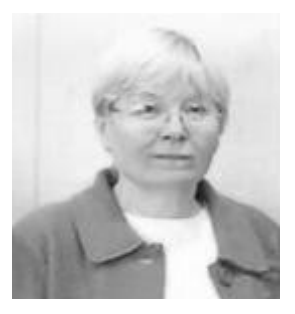

Magdaléna Př́ivarová

Prof. Dr., Professor at the Department of Economics, University of Economics in Bratislava, Bratislava, Slovak Republic.

Research interests: international migration; EU labor market; international regulation of labor migration.

E-mail: magdalena.privarova@euba.sk 
negative net migration within all the EU countries in 2008, and in Latvia the negative net migration almost tripled between 2007 and 2008. The intention to leave the region is strongly related to economic decline and rising unemployment in it. The OECD data show that young men are more likely to emigrate in case of unemployment that occurs in the Baltic countries. Thus, the negative effect of emigration can be partially counteracted via the inflow of remittances and foreign investments.

The paper is structured as follows: in the next section, we have conducted literature review on the impacts of remittances on economic growth, emigration and remittances in the Baltics and the geography of remittances in the region in question. Then we have provided the research design. In the next section, we present the research results and the final section contains conclusion and discussion.

\section{Literature review}

\section{Impacts of remittances on economic growth}

According to the Encyclopedia of Geography (2010), remittances are "an important geographic phenomenon due to the sheer volume and extent of monetary flow from more affluent to poorer nations and the fact that they are disproportionately received by poorer members of these developing countries". Earlier studies on the effects of remittances on economic growth have shown that they often triggered economic growth. The direct effect of remittances on economic growth depends on the share allocated to productive investments. Therefore, a substantial body of the literature on remittances investigates their alternative destinations and the fundamental factors. As it is basically accepted, most of the money is spent on household consumption, housing, healthcare and the like (OCSE, 2006), even though the tendency to save seems to be higher for remittances than for domestic money (Cingolani \& Vietti, 2019; Fajnzylber \& Lopez, 2008). Households' decisions to invest is determined by the money that will remain available after their basic needs are satisfied, but it also depends on the conditions of the local economic environment, especially tax policy, the financial market, interest rates, etc. (Maimbo \& Ratha, 2005).

Even if remittances are not used for investments but for consumption only, they can also trigger economic growth through higher production volume and employment rate. This indirect "multiplier effect" can produce 2-3 additional units of GDP for each unit of remittance inflow (Karpestam, 2012).

Meyer \& Shera (2017) researched the influence of remittances on economic growth in Bulgaria Albania, Bosnia Herzegovina, Moldova, Macedonia and Romania in the period of 1999-2013 and found out that remittances positively affect economic growth, an increase in remittances by one unit increases GDP by $0.293 \%$.

Cismas et al. (2019) have researched the impact of remittances on economic growth in Romania during 1996-2017 and concluded that the inflow of remittances that got to the country via official channels did not have significant influence on economic growth, however the inflow of remittances that enter the country via informal channels had a much higher impact.

El-Hamma (2019) has researched the effects of remittances on economic growth in 14 Middle East and North Africa (MENA) countries during 1982-2016. The author has tested the hypothesis that "the effect of remittances on economic growth varies depending on the level of financial development and institutional environment in recipient countries". The 


\section{EMIGRATION, REMITTANCES AND ECONOMIC GROWTH}

results of their research have revealed that remittances trigger economic growth in the countries with a developed financial system and a strong institutional environment.

Similar research on the effects of remittances on economic growth in developing countries during 1990-2014 was conducted by Devasagayam et al. (2016) and it supported the same conclusions. The latter research has shown that remittances trigger economic growth only in "more open" economies due to the fact that remittances alone are not sufficient for growth. The extent of their effect on economic growth is determined by the quality of domestic institutions and the macroeconomic environment in the receiving countries. Unlike "less open" economies, "more open" economies are characterized by better financial markets and institutions and also by higher ability to turn remittances into profitable investments which, in turn, induce the rate of economic growth. Positive impact of remittances on economic growth in the MENA countries during 1977-2014 has been also documented by Devasagayam et al. (2016).

Studies aimed at researching the effect of remittances on GDP in European countries have also supported the results on the considered positive effect of remittances on economic growth. In particular, Comes et al. (2018) have researched the impact of remittances and FDI on economic growth in the Central and Eastern European countries during 2010-2016 and shown there is a positive impact of both remittances and FDI on economic growth in the analyzed countries.

However, a similar research and on the same region conducted by Gjini (2013) has shown that remittances negatively affected economic growth of the CEE countries during 1996-2010. In particular, this author has recorded that an increase in remittances by $10 \%$ decreases the output by about $0.9 \%$. The author has emphasized that the key concern of the CEE countries after the collapse of communism systems has been to develop the policies to increase their standard of living up to the level of Western European countries. Economic growth achieved after 1991 by the CEE countries has been remarkable. However, the determinants that have affected such an economic growth in the region vary from capital investments to foreign direct investment, foreign aid, institutional factors, labor surplus, technological changes, trade, research and development, etc.

Research of Gapen et al. (2009) has shown that remittances "do not seem to make a positive contribution to economic growth...Perhaps the most persuasive evidence in support of this finding is the lack of a single example of a remittances success story: a country in which remittances-led growth contributed significantly to its development...But no nation can credibly claim that remittances have funded or catalyzed significant economic development".

Different conclusions can be drawn; however, most of them claim that remittances might be a significant contributor to economic growth provided they are used for investments in more open economies with developed financial institutions and other infrastructure. We assume a significant influence of remittances for economic growth of the Baltics based on high emigration flows since joining the EU in 2004. In the next part of our paper, we will be dealing in more detail with the relationship between emigration and remittances in the region in question.

\section{Emigration and remittances in the Baltics}

While integrating to the EU, the Baltics have faced many economic and political

problems which revealed the weaknesses of their economic policies, financial systems and 
social security systems (Kerikmäe et al., 2018). Although the Baltic economies have shown rapid economic growth since joining the EU in 2004, the fundamentals of Baltic economies have remained unstable and the financial and economic crisis has clearly shown their major weaknesses.

In particular, cheap foreign capital was used mostly for consumption, not for investment (Poissonnier et al., 2017).

The Baltics are an obvious example of the countries where the current emigration has drawn the attention of policy-makers seeking to minimize the potential negative effects from the emigration of young and skilled workers (Hazans, 2016, 2019). Latvia and Lithuania in particular have experienced high population outflows after joining the EU and during the 2008 crisis especially (OECD, 2013). These outflows which have disproportionately involved young population, have worsened the demographic situation of the Baltic states which are currently facing the problem of a rapidly aging population (Włodarska-Frykowska, 2018).

According to the research of the European Commission on the movement of skilled labour, none of the three Baltic states has a comprehensible, strategic approach to attracting return migrants from other countries. Thus, the negative effect of emigration can be partially counteracted only via the inflow of remittances and foreign investments.

Despite the fact that the issue of emigration in the region since 2004 has been recognized, there are, however, not many studies on the effects of remittances on economic growth in this region. According to some studies, remittances in the Baltics have been used by the local households for buying real estate, other goods and services. Around $63 \%$ of migrants in the Baltics have used remittances simply for everyday needs (Hazans, 2003). At the same time, there is a positive role of remittances in increasing the standards of living in Estonia. Here the households have faced less financial difficulties if their family members were sending remittances (Hazans \& Philips, 2009).

Rausser et al. (2018) have investigated the effect of remittances in the Baltics and found out they had a high and positive impact on economic development in the region during 2005-2015. However, minimum wages in Latvia and Lithuania appeared to be more significant factors of economic development in the region rather than remittances.

Kumar \& Stauvermann (2014) have explored the effects of remittances on the output per worker in Lithuania during 1980-2012 and found out an unidirectional causation from remittances to output per worker in the country.

In our paper, we have analyzed the effect of remittances on economic growth of the Baltics as a region. It should be noted that the volume of remittances to the Baltics has been declining during the recent years. In Estonia, a decreasing trend of remittances can be observed since 2013 (see Fig. 1), in Latvia - since 2010 (Fig. 2) and in Lithuania - since 2014 (Fig. 3). 
EMIGRATION, REMITTANCES AND ECONOMIC GROWTH

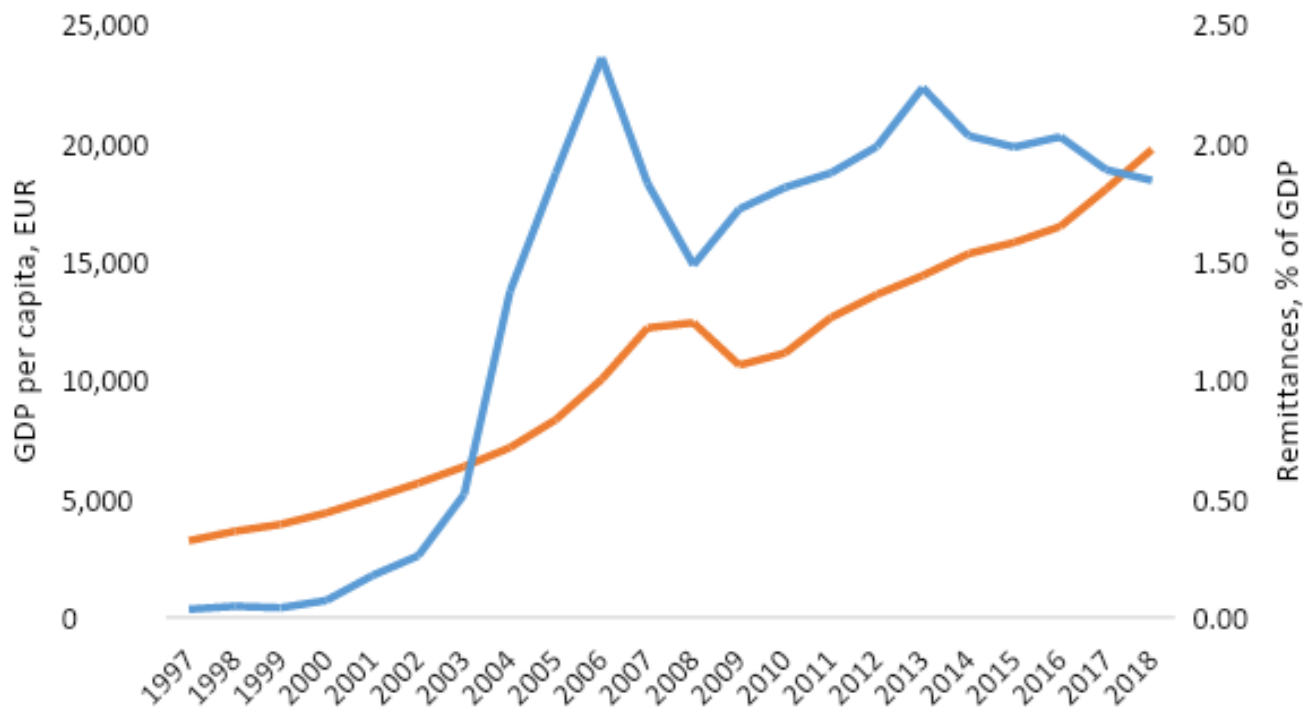

Figure 1 - GDP per capita and remittances in Estonia, 1997-2018

(Source: created by the author based on the World Bank Data, 2018b)

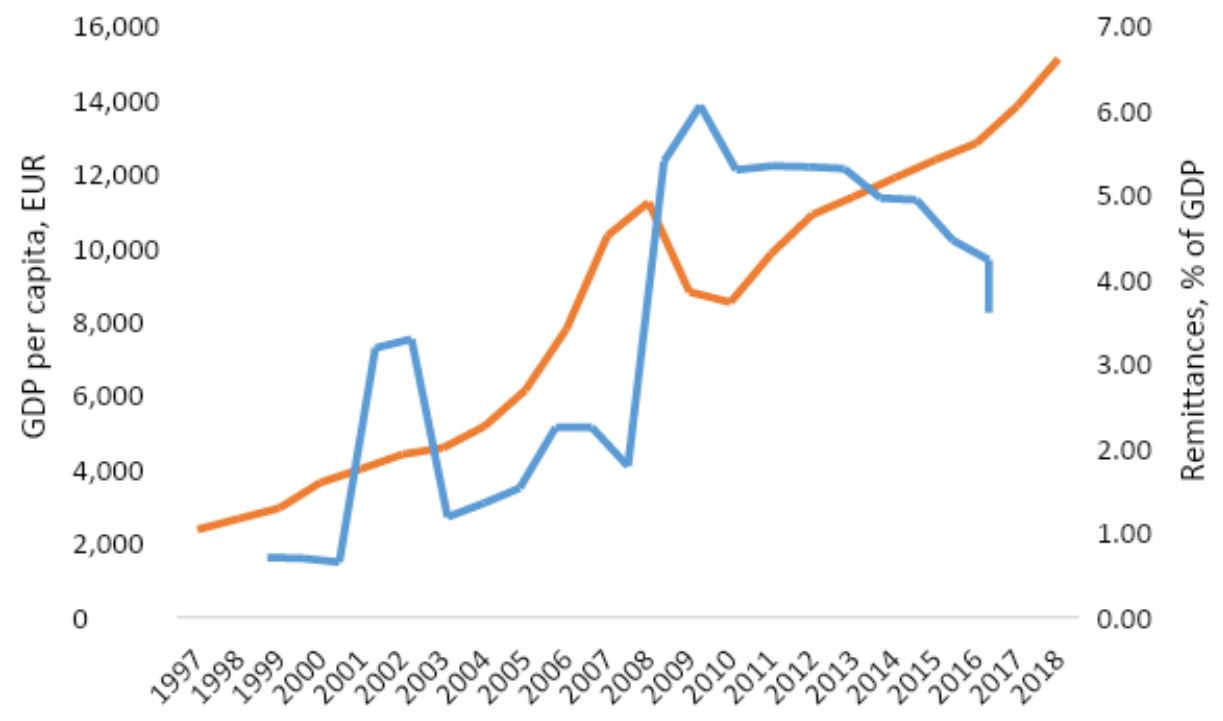

Figure 2 - GDP per capita and remittances in Latvia, 1997-2018

(Source: created by the author based on the World Bank Data, 2018b) 


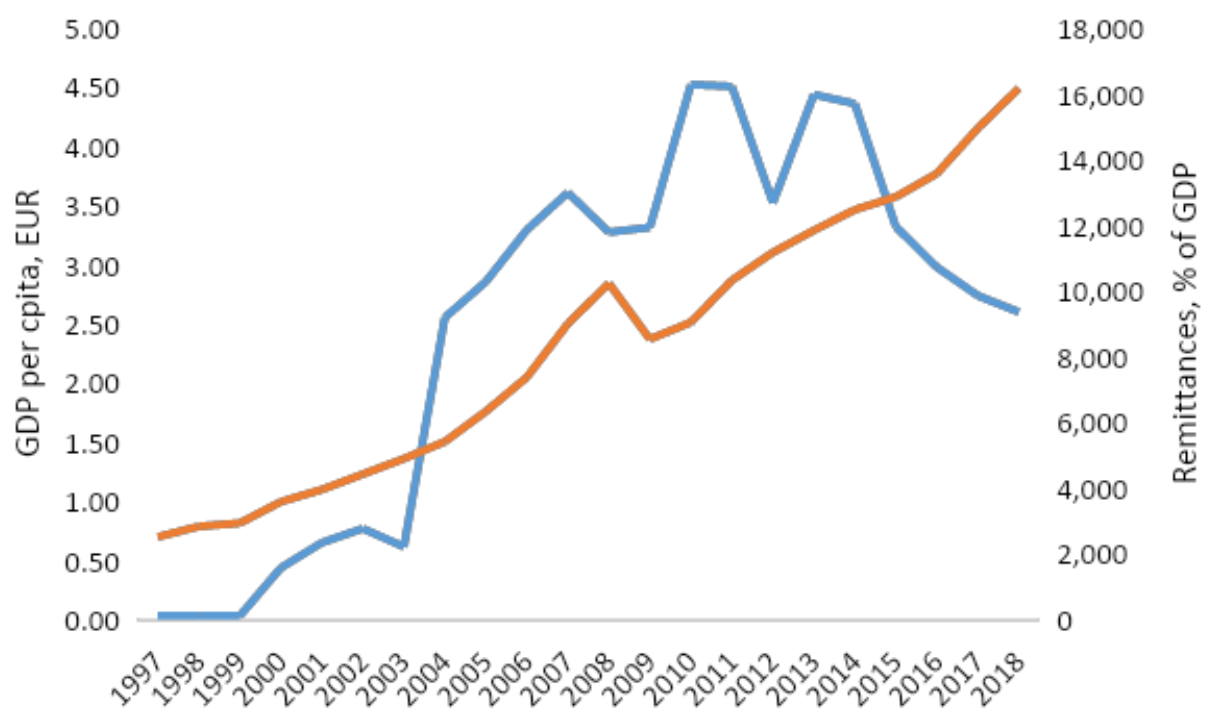

Figure 3 - GDP per capita and remittances in Lithuania, 1997-2018 (Source: constructed by author based on World Bank, 2018b)

Given the opposite GDP growth and remittances in all the Baltic countries in the recent years, our research will contribute to literature by revealing whether remittances are a significant factor of economic growth in the region in question. In the next section, we consider the historical geography of remittances in the Baltic and the Brexit as a significant factor affecting remittances flows in the region.

\section{Geography of remittances in the Baltic}

When considering the effects of remittances on Baltic economics, their geography should be emphasized. According to the available World Bank data for 2010-2017 on the bilateral remittances flows (World Bank, 2017), the countries from which the highest shares of remittances have been sent to all three Baltic countries used to be Germany, Russia, Ukraine, United Kingdom and the United States. However, at the same time, the Baltic countries differ from each other by the geography of sending countries. In particular, according to the latest data, higher volume of remittances than to other Baltic states are sent to Latvia from Australia and Canada, while Estonia receives higher remittance flows than Lithuania and Latvia from Finland. Lithuania experiences much higher remittances from Russia, the United Kingdom, the United States, Germany, Ireland, Norway, Spain and Poland.

According to the latest available World Bank data on remittances (World Bank, 2017), the share of remittances from the United Kingdom in their total amount to Estonia was 5\%, to Latvia $-21 \%$ and to Lithuania $-22.8 \%$. As the United Kingdom is a major remittance source for the Baltic Region, the Brexit will have a significant impact on emigration flows, i.e., on the geographical redistribution of remittances in the region and, consequently, on their contribution to economic growth.

It is not known so far how remittances flows will be changed. Brexit will most probably create a significant financial and political gap. The power in the EU bloc will move towards Germany and France. However, answers to other questions are not so clear. In particular, questions about the future directions of the EU development will arise when the 


\section{EMIGRATION, REMITTANCES AND ECONOMIC GROWTH}

loss of the largest member of the region outside the euro area shifts the focus more to the euro area members and creates a huge gap in the EU budget.

Other Member States are working to adapt their internal EU policies and are now developing new regional groups and coalitions to influence the EU's orientation towards a stronger Franco-German partnership.

Currently, the Northern member states are developing stronger cooperation among themselves within the EU. In particular, Nordic cooperation continues, involving the three Baltic States known as the North-Baltic Six (NB6) (Hilmarsson, 2019). Another notable effort to strengthen cooperation is the Dutch-led New Hanseatic League (Lewicki et al., 2019), which brought together the finance ministers of the Nordic and Baltic countries, the Netherlands and Ireland.

The above changes in power and in the development of cooperation between the Member States will undoubtedly bring about changes in migration flows and the amount of remittances in the Baltic. However, these changes can only be monitored after a certain period of time. Historical data available thus far may shed light on the impact of remittances on economic growth in the Baltic before Brexit. In the section below, we present a research design framework of the paper.

Table 1 - Description of variables

(Source: author calculation)

\begin{tabular}{|c|c|c|c|c|}
\hline Variable & Description & Unit of measure & Source & $\begin{array}{c}\text { Expected sign } \\
\text { of the influence } \\
\text { on savings }\end{array}$ \\
\hline $\begin{array}{l}\text { 1_GDP_per_cap: } \\
\text { dependent } \\
\text { variable }\end{array}$ & $\begin{array}{l}\text { Logarithm of } \\
\text { GDP per capita }\end{array}$ & $\begin{array}{c}\text { Current } \\
\text { prices, EUR } \\
\text { per capita }\end{array}$ & Eurostat, 2020b & \\
\hline Remittances_perc & $\begin{array}{l}\text { Remittances in the } \\
\text { receiving } \\
\text { countries }\end{array}$ & $\%$ of GDP & $\begin{array}{l}\text { World Bank, } \\
\text { 2018b }\end{array}$ & + \\
\hline $\begin{array}{l}\text { Gross_fixed_cap_ } \\
\text { form_perc }\end{array}$ & $\begin{array}{l}\text { Logarithm of } \\
\text { gross fixed capital } \\
\text { formation }\end{array}$ & $\%$ of GDP & $\begin{array}{l}\text { World Bank, } \\
2020\end{array}$ & + \\
\hline Unempl_perc & $\begin{array}{l}\text { Logarithm of the } \\
\text { number of } \\
\text { unemployed } \\
\text { people }\end{array}$ & $\begin{array}{l}\% \text { of active } \\
\text { population } \\
\text { aged } 20-64\end{array}$ & Eurostat, 2019 & - \\
\hline FDI_inflow_perc & $\begin{array}{lr}\begin{array}{l}\text { Foreign } \\
\text { investment, } \\
\text { inflows }\end{array} & \text { net } \\
\end{array}$ & $\%$ of GDP & $\begin{array}{l}\text { World Bank, } \\
\text { 2018a }\end{array}$ & + \\
\hline REER & $\begin{array}{l}\text { Real effective } \\
\text { exchange rate }\end{array}$ & Index & Eurostat, 2020a & $-/+$ \\
\hline Crisis & Crisis 2008 & $\begin{array}{c}\text { Dummy } \\
\text { variable }(0,1)\end{array}$ & & - \\
\hline
\end{tabular}




\section{Research design}

\section{Hypothesis and model specification}

We have tested the following hypothesis:

$H_{0}$ : Remittances had a positive influence on economic growth in the Baltics during 2010-2017.

When exploring the effect of remittances on economic growth, other authors have used data on both GDP per capita (Abduvaliev \& Bustillo, 2019; Comes et al., 2018; Gjini, 2013; Mehedintu et al., 2019 and GDP per capita growth (Cismaș et al., 2019; El Hamma, 2019; Ghosh Dastidar, 2017; Meyer \& Shera, 2017).

Based on the above theoretical background and empirical findings, we developed a regression model to assess the impact of remittances on economic growth in the Baltics, along with other macroeconomic determinants as control variables (Tab. 1) during the period of 1997 - 2018. Our time frame is limited due to data availability.

$$
\begin{gathered}
l_{-} G D P \_p e r \_c a p=a_{0}+a_{1} \text { Remittances_perc }+a_{2} \text { Gross_fixed_cap_form_perc }+ \\
a_{3} \text { Unempl_perc }+a_{4} F D I \_i n f l o w_{-} \text {perc }+a_{5} R E E R+a_{6} \text { Crisis }+U_{i}
\end{gathered}
$$

\section{Results}

Regression analysis was performed using fixed effects and OLS estimation methods. Summary statistics are given in Tab. 2. The results of the regression analysis are shown in Table 3. Tests for capturing different groups, heteroscedasticity and error distribution are shown in Table 4.

Table 2. Summary statistics

Source: calculated by the author

\begin{tabular}{|l|c|c|c|c|c|}
\hline \multicolumn{1}{|c|}{ Variable } & Mean & Median & S.D. & Min & Max \\
\hline 1_GDP_per_cap & 8.958 & 9.106 & 0.5805 & 7.766 & 9.89 \\
\hline Remittances_perc & 2.386 & 2.029 & 1.688 & 0.02729 & 6.044 \\
\hline Gross_fixed_cap_form_perc & 24.73 & 23.86 & 5.015 & 16.91 & 36.82 \\
\hline Unempl_perc & 10.78 & 10.85 & 3.704 & 4.200 & 19.30 \\
\hline FDI_inflow_perc & 5.098 & 4.227 & 3.990 & -3.104 & 22.18 \\
\hline REER & 94.86 & 96.95 & 10.16 & 64.89 & 114.2 \\
\hline Crisis & 0.04545 & 0.0000 & 0.2099 & 0.0000 & 1.000 \\
\hline
\end{tabular}

In our basic model, we have included six determinants of economic growth which are: remittances, gross fixed capital formation, unemployment rate, FDI inflows, the real exchange rate and a dummy variable in times of crisis (Barcenilla et al., 2019; Chinnakum et al., 2013; de la Fuente-Mella et al., 2019; Fadejeva \& Melihovs, 2008; Goliuk, 2017; Norkus, 2016; Rusu \& Roman, 2018; Yazdi, 2019; Yucel, 2014).

We made two modifications to the basic fixed effects model 1 (model 2 and model 3 ). A test to capture the different groups has shown in all three cases estimating the fixed effects was the correct method of estimation. However, Wald's heteroskedasticity test for the 


\section{EMIGRATION, REMITTANCES AND ECONOMIC GROWTH}

baseline model 1 and the modified model 2 showed that heteroskedasticity was present in there. Remittances appeared significant in all the three fixed-effect models. The last modified fixed effects, Model 3, does not demonstrate any heteroskedasticity and residual error. As expected, remittances had a positive impact on economic growth in the Baltics during 19972018.

Table 3 - Regression results

(Source: calculated by the author)

\begin{tabular}{|c|c|c|c|c|c|}
\hline Independent variables & $\begin{array}{c}\text { Model } 1 \\
\text { Baseline } \\
\text { model } \\
\text { Fixed effects }\end{array}$ & $\begin{array}{c}\text { Model } 2 \\
\text { Modified } \\
\text { model } \\
\text { Fixed effects }\end{array}$ & $\begin{array}{c}\text { Model } 3 \\
\text { Modified } \\
\text { model } \\
\text { Fixed effects }\end{array}$ & $\begin{array}{c}\text { Model } 4 \\
\text { Baseline } \\
\text { model } \\
\text { OLS } \\
\text { RBS }\end{array}$ & $\begin{array}{c}\text { Model } 5 \\
\text { Modified } \\
\text { model } \\
\text { OLS } \\
\text { RBS }\end{array}$ \\
\hline Const & $\begin{array}{l}6.15^{* * * *} \\
(0.53)\end{array}$ & $\begin{array}{l}5.91 * * * \\
(0.31)\end{array}$ & $\begin{array}{c}8.88^{* * * *} \\
(0.13)\end{array}$ & $\begin{array}{c}5.13 * * * \\
(0.6)\end{array}$ & $\begin{array}{c}5.07 * * * \\
(0.43)\end{array}$ \\
\hline Remittances_perc & $\begin{array}{c}0.12^{* * * *} \\
(0.02)\end{array}$ & $\begin{array}{c}0.12 * * * \\
(0.02)\end{array}$ & $\begin{array}{c}0.29 * * * * \\
(0.02)\end{array}$ & $\begin{array}{c}0.05^{* * * *} \\
(0.01)\end{array}$ & $\begin{array}{c}0.05^{* * * *} \\
(0.01)\end{array}$ \\
\hline $\begin{array}{l}\text { Gross_fixed_cap_form_p } \\
\text { erc }\end{array}$ & $\begin{array}{l}-0.00 \\
(0.00)\end{array}$ & & & $\begin{array}{l}-0.00 \\
(0.00)\end{array}$ & \\
\hline Unempl_perc & $\begin{array}{c}-0.04 * * * \\
(0.00)\end{array}$ & $\begin{array}{c}-0.04 * * * \\
(0.00)\end{array}$ & $\begin{array}{c}-0.05 * * * \\
(0.01)\end{array}$ & $\begin{array}{c}-0.04 * * * * \\
(0.01)\end{array}$ & $\begin{array}{c}-0.04 * * * * \\
(0.00)\end{array}$ \\
\hline FDI_inflow_perc & $\begin{array}{c}0.00 \\
(0.00)\end{array}$ & & & $\begin{array}{c}0.02^{* *} \\
(0.00)\end{array}$ & $\begin{array}{c}0.02 * * * \\
(0.00)\end{array}$ \\
\hline REER & $\begin{array}{c}0.03^{* * * *} \\
(0.00)\end{array}$ & $\begin{array}{c}0.03^{* * * *} \\
(0.00)\end{array}$ & & $\begin{array}{c}0.04 * * * * \\
(0.00)\end{array}$ & $\begin{array}{c}0.04 * * * * \\
(0.00)\end{array}$ \\
\hline Crisis & $\begin{array}{c}-0.16 \\
(0.11)\end{array}$ & & & $\begin{array}{c}-0.18 * * * \\
(0.06)\end{array}$ & $\begin{array}{c}-0.18 * * * \\
(0.06)\end{array}$ \\
\hline & 66 & 66 & 66 & 66 & 66 \\
\hline Number of countries & 3 & 3 & 3 & 3 & 3 \\
\hline LSDV R-squared & 0.91 & 0.91 & 0.76 & & \\
\hline Within R-squared & 0.91 & 0.9 & 0.75 & & \\
\hline R-squared & & & & & 0.88 \\
\hline Adjusted R-squared & & & & & 0.87 \\
\hline
\end{tabular}

Note: Standard errors in parentheses.

$* * * \mathrm{p}<0.01, * * \mathrm{p}<0.05, * \mathrm{p}<0.1$

The OLS estimation (base model 4 and adjusted model 5) shows that the impact of remittances, together with the unemployment rate, FDI inflows, the real exchange rate and the dummy variable on the crisis, appeared to be in line with our expectations. Our results show similar effects within and between impacts in terms of the impact of remittances on economic growth of the Baltic countries.

\section{Conclusion and discussion}

Here we have tested the hypothesis that remittances had a positive impact on economic growth in the Baltic during 1997-2018, using fixed effects and OLS estimation methods. Multiple regression analysis was used to examine the relationship between remittances and economic growth. In addition to the data on remittances, we have used the variables such as gross fixed capital formation, unemployment rate, FDI inflows, real exchange rate and the dummy variable on crisis in 2008. Tests for different group captures, heteroscedasticity, error 
distribution were used to test the quality of the regression model. Our regression analysis has shown that remittances make a positive and significant contribution to the economic growth in the Baltic countries.

Table 4 - Tests for differing group intercepts, heteroscedasticity, error distribution (Source: calculated by the author)

\begin{tabular}{|l|c|c|c|c|c|}
\hline \multicolumn{1}{|c|}{ Tests/Models } & $\begin{array}{c}\text { Model 1 } \\
\text { Baseline model } \\
\text { Fixed effects }\end{array}$ & $\begin{array}{c}\text { Model 2 } \\
\text { Modified model } \\
\text { Fixed effects }\end{array}$ & $\begin{array}{c}\text { Model 3 } \\
\text { Modified model } \\
\text { Fixed effects }\end{array}$ & $\begin{array}{c}\text { Model 4 } \\
\text { Baseline model } \\
\text { OLS } \\
\text { RBS }\end{array}$ & $\begin{array}{c}\text { Model 5 } \\
\text { Modified } \\
\text { model } \\
\text { OLS } \\
\text { RBS }\end{array}$ \\
\hline $\begin{array}{l}\text { Tests for capturing } \\
\text { different groups }\end{array}$ & 10.02 & 14.55 & 22.42 & \\
\hline $\begin{array}{l}\text { Wald test for } \\
\text { heteroscedasticity }\end{array}$ & $(0.00)$ & $(0.00)$ & $(0.00)$ & & \\
\hline Test statistics for & 9.18 & 11.38 & 1.39 & & \\
normality of residual & $(0.02)$ & $(0.00)$ & $3.0 .7)$ & 0.14 & $(0.12)$ \\
test & $(0.14)$ & $(0.13)$ & $(0.19)$ & & \\
\hline $\begin{array}{l}\text { White's test for } \\
\text { heteroscedasticity }\end{array}$ & & & & 28.68 & $(0.19)$ \\
\hline
\end{tabular}

Note: $p$-value in parentheses

RBS - robust standard errors

We emphasize the importance of analyzing the geography of remittances, especially under Brexit conditions, given the high share of remittances that arrive in the Baltics from the United Kingdom. The contribution of further studies should therefore focus on examining the effects of Brexit on remittances flows from the United Kingdom to the Baltics. Furthermore, the effects of the coronavirus pandemic should be examined to see if the loss of remittances from senders who have been severely affected by the virus can cause an economic downturn in the Baltics and when these negative effects can be mitigated.

We also emphasize that remittances can increase economic growth if they are used for investment purposes. This study has been focused on the relationship between remittances and economic growth, and it is therefore useful for further research to examine how remittances are then used in the Baltics.

\section{References:}

Abduvaliev, M. \& Bustillo, R. (2019). Impact of remittances on economic growth and poverty reduction amongst CIS countries. Post-Communist Economies, 1-22.

Barcenilla, S., Gimenez, G. \& López-Pueyo, C. (2019). Differences in Total Factor Productivity Growth in the European Union: The role of Human Capital by Income Level. Prague Economic Papers, 28(1), 70-85.

Chinnakum, W., Sriboonchitta, S. \& Pastpipatkul, P. (2013). Factors affecting economic output in developed countries: A copula approach to sample selection with panel data. International Journal of Approximate Reasoning, 54(6), 809-824.

Cingolani, P. \& Vietti, F. (2019). 'My Parents Fell behind': Social Remittances, Integration and Generational Change Among Moldovan Immigrants. Journal of International Migration and Integration, 10(7). 


\section{EMIGRATION, REMITTANCES AND ECONOMIC GROWTH}

Cismaş, L. M., Curea-Pitorac, R. I. \& Vădăsan, I. (2019). The impact of remittances on the receiving country: Some evidence from Romania in European context. Economic Research, 1-22.

Comes, C.-A. (2018). The Impact of Foreign Direct Investments and Remittances on Economic Growth: A Case Study in Central and Eastern Europe. Sustainability, 10(1), 238.

de la Fuente-Mella, H., Vallina-Hernandez, A. M. \& Fuentes-Solís, R. (2019). Stochastic analysis of the economic growth of OECD countries. Economic Research, 1-14.

Devasagayam, P. R., Calderon, F. J. M. \& Motyl, N. A. (2016). A Cross-National Empirical Investigation of Music Streaming Behavior. International Journal of Academic Research in Business and Social Sciences, 6(5), 152-171.

El Hamma, I. (2019). Migrant Remittances and Economic Growth: The Role of Financial Development and Institutional Quality. Economics and Statistics, 503d, 123-142.

Eurostat. (2019). Unemployment by sex and age - Annual average. Eurostat. http://appsso.eurostat.ec.europa.eu/nui/submitViewTableAction.do

Eurostat. (2020a). Industrial countries' effective exchange rates - Annual data. http://appsso.eurostat.ec.europa.eu/nui/submitViewTableAction.do

Eurostat. (2020b). Real GDP per Capita. https://ec.europa.eu/eurostat/tgm/table.do?tab=table\&init=1\&plugin=1\&pcode=sdg_08_10\&la nguage $=$ en

Fadejeva, L. \& Melihovs, A. (2008). The Baltic states and Europe: Common factors of economic activity. Baltic Journal of Economics, 8(1), 75-96.

Fajnzylber, P. \& Lopez, J. H. (Eds.). (2008). Remittances and Development: Lessons from Latin America. The World Bank.

Gapen, M. T., Chami, R., Montiel, P., Barajas, A. \& Fullenkamp, C. (2009). Do Workers' Remittances Promote Economic Growth? IMF Working Papers, 09(153), 1.

Ghosh Dastidar, S. (2017). Impact of Remittances on Economic Growth in Developing Countries: The Role of Openness. Global Economy Journal, 17(2).

Gjini, A. (2013). The Role of Remittances on Economic Growth: An Empirical Investigation Of 12 CEE Countries. International Business \& Economics Research Journal, 12(2), 193.

Goliuk, V. (2017). Impact Of Monetary And Non-Monetary Factors On Economic Development Of The Baltic Countries. Actual Problems of International Relations, 133, 117-123.

Hazans, M. (2003). Determinants of Inter-Regional Migration in the Baltic Countries. SSRN Electronic Journal.

Hazans, M. (2016). Migration Experience of the Baltic Countries in the Context of Economic Crisis. In: M. Kahanec \& K. F. Zimmermann (Eds.), Labor Migration, EU Enlargement, and the Great Recession. Springer Berlin Heidelberg.

Hazans, M. (2019). Emigration from Latvia: A Brief History and Driving Forces in the Twenty-First Century. In: R. Kaša \& I. Mieriņa (Eds.), The Emigrant Communities of Latvia. Springer International Publishing.

Hazans, M. \& Philips, K. (2009). The Post-Enlargement Migration Experience in the Baltic Labor Markets. In: M. Kahanec \& K. F. Zimmermann (Eds.), EU Labor Markets After PostEnlargement Migration. Springer Berlin Heidelberg. 
Hilmarsson, H. (2019). Nordic-Baltic Cooperation: Opportunities, Divisions And External Threats. Regional Formation and Development Studies, 29(3), 73-85.

Karpestam, R. P. D. (2012). Dynamic multiplier effects of remittances in developing countries. Journal of Economic Studies, 39(5), 512-536.

Kerikmäe, T., Chochia, A. \& Atallah, M. (2018). The Baltic States in the European Union. In T. Kerikmäe, A. Chochia, \& M. Atallah, Oxford Research Encyclopedia of Politics. Oxford University Press.

Kumar, R. R. \& Stauvermann, P. J. (2014). Exploring the Effects of Remittances on Lithuanian Economic Growth. Engineering Economics, 25(3), 250-260.

Lewicki, G., Kutwa, K. \& Chapman, A. (2019). Hansa 2.0: A return to the Golden Age of trade. Polish Economic Institute.

Maimbo, S. M. \& Ratha, D. (Eds.). (2005). Remittances: Development impact and future prospects. World Bank.

Mehedintu, A., Soava, G. \& Sterpu, M. (2019). Remittances, Migration and Gross Domestic Product from Romania's Perspective. Sustainability, 12(1), 212.

Meyer, D. \& Shera, A. (2017). The impact of remittances on economic growth: An econometric model. EconomiA, 18(2), 147-155.

Norkus, Z. (2016). A Comparison of the Economic Growth of the Baltic States between the Two World Wars. World Political Science, 12(1), 1-23.

OCSE. (2006). International migration outlook: Annual report: 2006 edition. OECD.

OECD. (2013). Coping with Emigration in Baltic and East European Countries. OECD.

Poissonnier, A. (2017). European Commission, \& Directorate-General for Economic and Financial Affairs. The Baltics: Three countries, one economy.

Rausser, G., Strielkowski, W., Bilan, Y. \& Tsevukh, Y. (2018). Migrant remittances and their impact on the economic development of the Baltic states. Geographica Pannonica, 22(3), 165-175.

Rusu, V. D. \& Roman, A. (2018). An empirical analysis of factors affecting competitiveness of C.E.E. countries. Economic Research, 31(1), 2044-2059.

Włodarska-Frykowska, A. (2018). Migration processes in the Baltic States - the dynamic of change. Eastern Review, 6.

World Bank. (2017). Migration and Remittances Data. World Bank.

World Bank. (2018a). Foreign direct investment, net inflows (\% of GDP). https://data.worldbank.org/indicator/BX.KLT.DINV.WD.GD.ZS

World Bank. (2018b). Personal remittances, received (\% of GDP). https://data.worldbank.org/indicator/BX.TRF.PWKR.DT.GD.ZS

World Bank. (2020). Gross fixed capital formation (current US\$). https://data.worldbank.org/indicator/NE.GDI.FTOT.CD

Yazdi, S. K. (2019). Structural breaks, international tourism development and economic growth. Economic Research, 32(1), 1765-1776.

Yucel, G. E. (2014). FDI and Economic Growth: The Case of Baltic Countries. Research in World Economy, 5(2), 115 


\section{EMIGRATION, REMITTANCES AND ECONOMIC GROWTH}

Paper submitted

Paper accepted for publishing

Paper published online
07 July 2020

26 September 2020

30 November 2020 